\title{
The Influence of Damage to the Geomembrane Layer on the Seepage Pattern and Discharge at the Homogeneous Embankment Dam
}

\author{
AchsinWijayanto $^{1 *}$, Pitojo Tri Juwono ${ }^{2}$, Evi Nur Cahya ${ }^{2}$ \\ ${ }^{1}$ PT Indra Karya (Persero) Division of Engineering I, Malang, 65115, Indonesia \\ ${ }^{2}$ Water Resources Engineering Department, Universitas Brawijaya, Malang, 65145, \\ Indonesia \\ achsinw@gmail.com
}

Received 01-01-2021; accepted 08-02-2021

\begin{abstract}
Placing the geomembrane layer on the upstream slope can control the seepage in homogeneous dams. Poor geomembrane design, construction and maintenance caused damage to the geomembrane that caused a leak through the dam body. This study discusses the effect of damage on the geomembrane layer at the homogeneous embankment dam on the seepage pattern and discharge. The study location is in the Sianjo Anjo dam, Aceh Singkil district, a homogeneous dam with a geomembrane layer located in the dam body's upstream part. The damage of the geomembrane layer is assumed caused by the various defect of locations and size. The results show that the seepage pattern (phreatic line) tends to be weak in the geomembrane layer without damage. Meanwhile, if the geomembrane layer is damaged, the larger the defects' width, the higher the phreatic line. However, the seepage pattern that occurs shows insignificant or almost the same. The seepage discharge increases with increasing defect width and decreasing defect location.
\end{abstract}

Keywords: damage, geomembrane, phreatic line, seepage

\section{Introduction}

Dams are constructed across rivers and valleys to retain water for protection from floods, water storage, diversion of water to canals in high lands, producing energy, and many more. Dams can be homogeneous (constructed using one type of soil) or zoned (consists of more than one type of soil with different hydraulic conductivities) [6,15]. A homogeneous dam is an embankment dam in with the material forming the dam's body consisting of $80 \%$ of materials with almost the same grade. Generally, the material used is semi- impermeable up to impermeable [1].

The control of seepage in homogeneous dams is carried out by placing an impermeable water layer in a geomembrane upstream part of the dam body to retain water [2]. Various control methods can be used to reduce the seepage through the dam, such as foundation cutoffs, transition zones, adequate

Cite this as: Wijayanto, A., Juwono, P.T., \& Cahya, E.N. (2021). The Influence of Damage to the Geomembrane Layer on the Seepage Pattern and Discharge at the Homogeneous Embankment Dam. Civil and Environmental Science Journal (Civense), 4(1), 76-83. doi: https://doi.org/10.21776/ub.civense.2021.00401.7 
core contact area, drainage material and blankets, upstream impervious blankets, impervious zones, and relief wells [14]. However, if the design, construction and maintenance are not good enough for the geomembrane, it can cause damage which results in leakage through the foundation and dam body. This study discusses the effect of damage to the geomembrane layer in the homogeneous embankment dam on the seepage pattern and discharge.

The analysis is carried out assuming that the geomembrane layer is damaged. Numerical modelling is becoming more widely used instead of experimental modelling to study seepage. SEEP/W, which GEO-SLOPE International Ltd. develops, is a powerful finite element software for modeling groundwater flow in porous media. SEEP/W can model simple saturated steady-state problems or sophisticated saturated/unsaturated transient analyses with atmospheric coupling at the ground surface. Therefore, the seepage analysis in this study used SEEP/W software based on the finite element numerical method $[15,16,17,20]$. The location of the damage is determined at the top, middle and bottom. Damage occurred in the form of defects with the width of the defects studied in this study were $10 \mathrm{~cm}, 25 \mathrm{~cm}$ and $50 \mathrm{~cm}$ [6]. Reservoir water level calculated in the seepage analysis is the normal water level (elevation $+14.80 \mathrm{~m})[12]$.

\section{Material and Methods}

\subsection{Location of Study}

The study's location is at the Sianjo Anjo Dam in the district of Aceh Singkil, a homogeneous dam with a geomembrane layer in the upstream part $[3,4,5]$. The Sianjo Anjo Dam, located at coordinates $02^{\circ} 25.5^{\prime}$ 69" S and $97^{\circ} 58.51^{\prime} 73^{\prime \prime} \mathrm{E}$ in Kain Golong Village, Aceh Singkil district, Aceh Province (Figure 1).

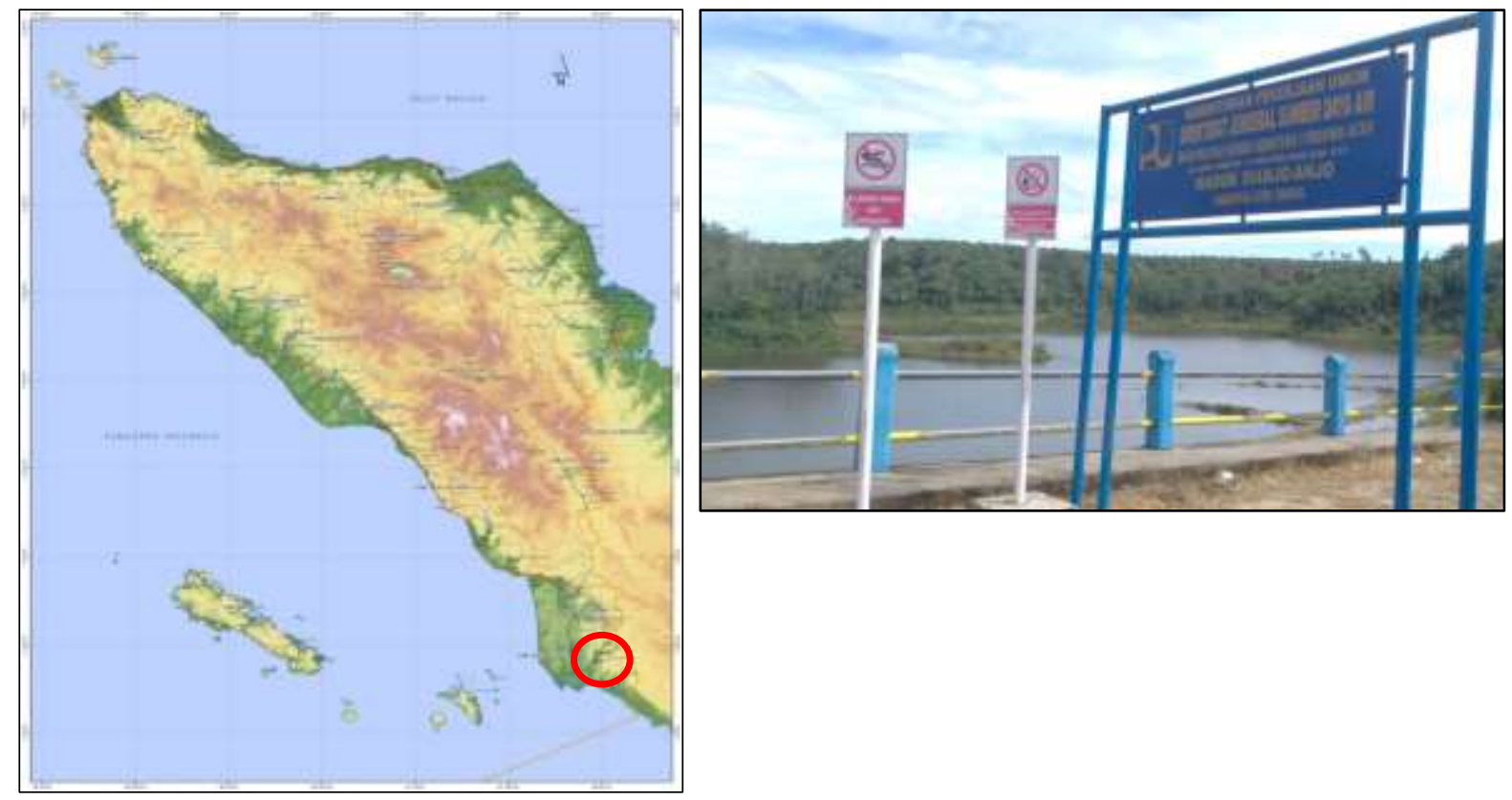

Figure 1. Location of Study

\subsection{Sianjo Anjo Dam}

The Sianjo Anjo Dam was completed in 2010. The benefits of the Sianjo-anjo Reservoir construction are as follows: delivery of clean water for households, irrigation, and supporting tourism development. The Sianjo Anjo Dam type is a homogeneous embankment dam with embankment material in the form of silty sand. The dam body's length is $192.65 \mathrm{~m}$, on the upstream slope a layer of geomembrane is installed as an impermeable layer. Figure 2 shows a cross section of the Sianjo Anjo 
dam reviewed in this study at sta $0+280$ and the location of the damage assumed to occur in the geomembrane layer $[3,4,5]$.

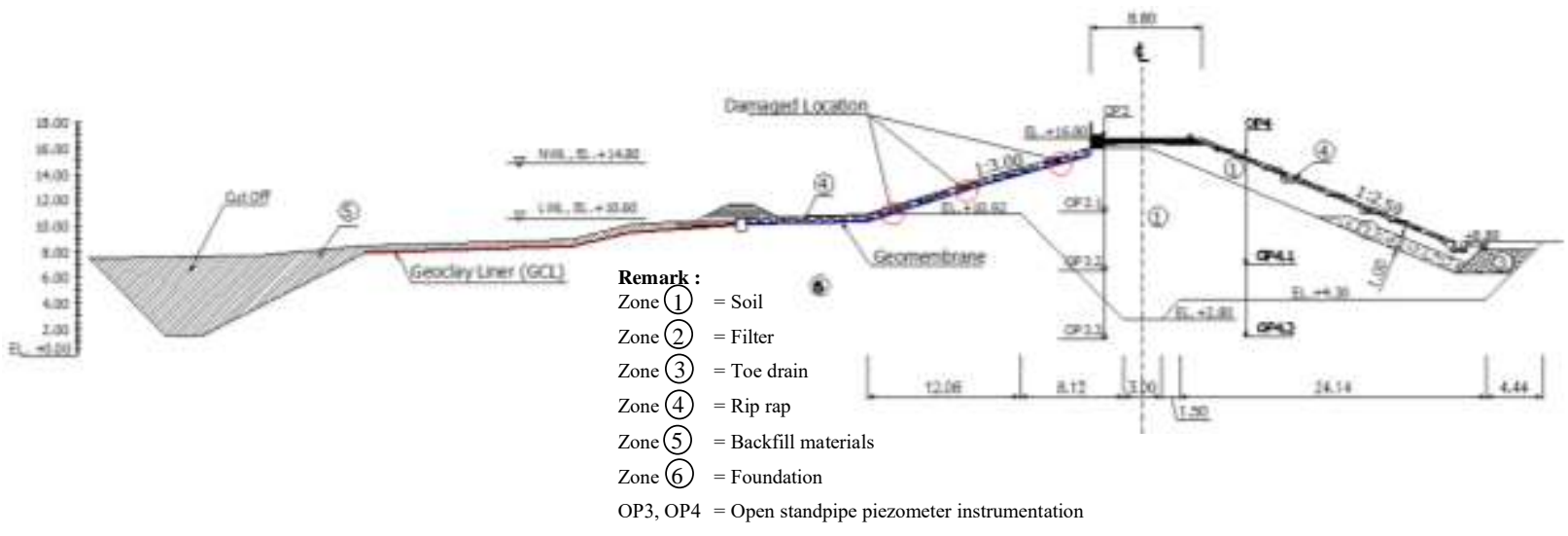

Figure 2. Cross Section of Sianjo Anjo Dam 0+280

\subsection{Data Collection}

The data were obtained from Balai Wilayah Sungai (BWS) Sumatera I, the dam owner and manager. The data required for the analysis are: [3] [4] [5] [7] [8]

1. Coefficient of Permeability

Table 1 shows material properties data of foundation and dam embankment used for seepage analysis, namely the coefficient of permeability $(\mathrm{K})$. Permeability is generally influenced by the material size and proportion [21].

Table 1. Coefficient of Permeability (K)

\begin{tabular}{ccc}
\hline Zone & Material & $\mathrm{K}(\mathrm{cm} / \mathrm{sec})$ \\
\hline Zone 1 & Soil & $1.04 \times 10^{-3}$ \\
Zone 2 & Filter & $1.00 \times 10^{-3}$ \\
Zone 3 & Toe drain & $1.00 \times 10^{-2}$ \\
Zone 4 & Riprap & $1.00 \times 10^{-1}$ \\
Zone 5 & Backfill material & $1.00 \times 10^{-4}$ \\
Zone 6 & Foundation & $1.53 \times 10^{-4}$ \\
\hline
\end{tabular}

Table 2. Data of open stand pipe piezometer on $26^{\text {th }}$

October 2019 (NWL, el. $+14.80 \mathrm{~m}$ )

\begin{tabular}{lrrr}
\hline Piezometer & $\begin{array}{c}\text { Coordinate X } \\
(\mathrm{m})\end{array}$ & $\begin{array}{c}\text { Coordinate } \\
\mathrm{Y}(\mathrm{m})\end{array}$ & \multicolumn{2}{c}{$\begin{array}{c}\text { Pore Water } \\
\text { Pressure }(\mathrm{kPa})\end{array}$} \\
\hline OP3.1 & 79.875 & 11.050 & 0.000 \\
OP3.2 & 79.875 & 6.516 & 46.482 \\
OP3.3 & 79.875 & 1.252 & 91.200 \\
OP4.1 & 93.375 & 6.993 & 21.672 \\
OP4.2 & 93.375 & 1.404 & 87.571 \\
\hline
\end{tabular}


The geomembrane's coefficient of permeability and the GCL data based on the benchmark are $1.00 \mathrm{x}$ $10^{-15} \mathrm{~cm} / \mathrm{s}$ and $1.00 \times 10^{-11} \mathrm{~cm} / \mathrm{s}$, respectively [9].

2. Data of OP3 and OP4 open stand pipe piezometer instrumentation readings

Data of OP3 and OP4 open stand pipe piezometer instrumentation readings (Table 2) result from field observations on $26^{\text {th }}$ October 2019 at the normal water level (NWL, el. $+14.80 \mathrm{~m}$ ). This data is used for calibration with analysis results.

3. The dam body seepage discharge's data measured on the V-notch instrument on 26th October, 2019 was $0.909 \mathrm{l} / \mathrm{s}$.

\subsection{Stages of Study}

Seepage analysis to determine the flow pattern (phreatic line) and the seepage discharge that comes out through the foundation and the dam body due to defecting of the geomembrane is performed in the following steps:

1. Collecting data, namely data on the geometry of the foundation and dam body, data on embankment material and foundation, data on readings of standpipe piezometer and v-notch.

2. Performed seepage analysis on the foundation and the body of the dam at the level of the reservoir water level in normal conditions (elevation $+14.80 \mathrm{~m}$ )

- Analysis of seepage conditions without damage/existing conditions

- The data will be Calibrate by comparing the results of the seepage analysis of existing conditions and the results of the seepage analysis using field instrumentation data (piezometer and v-notch readings) [10] [11] [13]

- Seepage analysis with the condition that there is damage to the geomembrane layer for each location and the width of the defect.

3. The results of the seepage analysis show the seepage pattern (phreatic line) and the seepage discharge [14][18][19].

\section{Result and Discussion}

The results of the seepage analysis of the existing conditions, as shown in Figure 3 show that if the geomembrane layer is not damaged, the phreatic level in the body of the dam tends to be lower. The seepage rate through the dam is $4.8971 \times 10^{-6} \mathrm{~m}^{3} / \mathrm{s} / \mathrm{m}$. With a dam body length of $192.65 \mathrm{~m}$, it was found that the seepage discharge was obtained of $0.9431 / \mathrm{s}$. Furthermore, the seepage discharge is close to the discharge measured on the v-notch instrument of $0.909 \mathrm{l} / \mathrm{s}$.

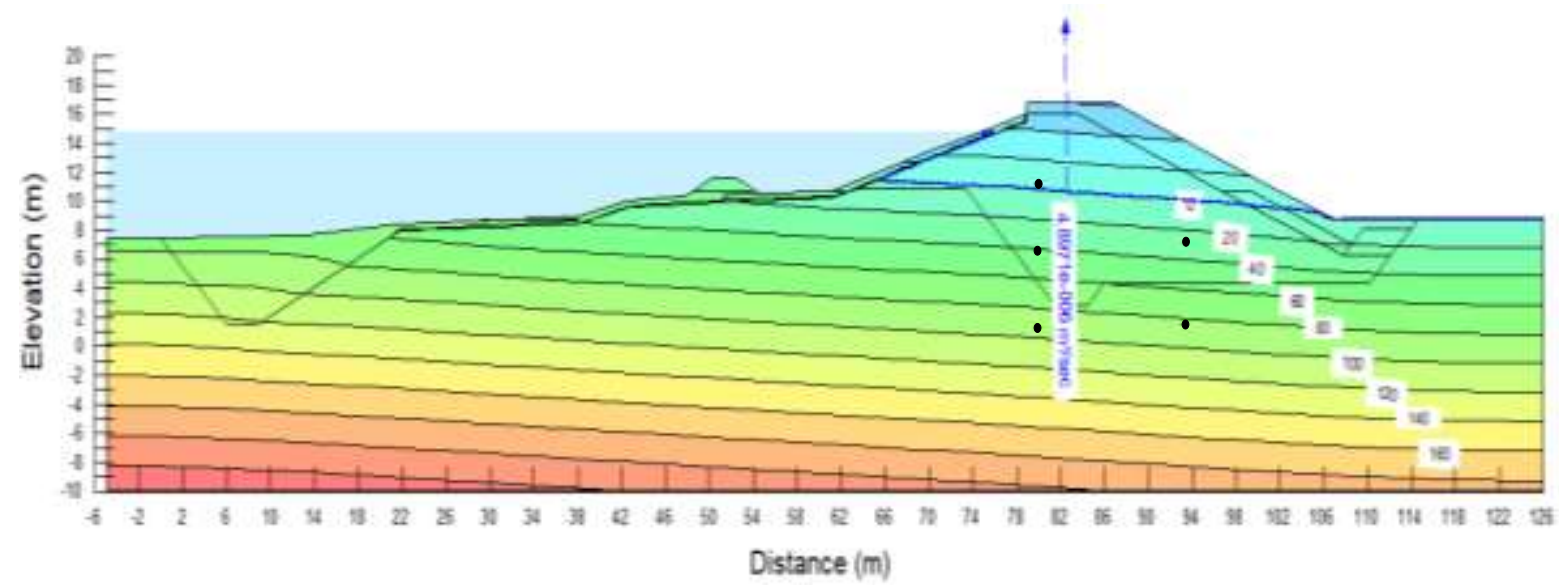

Figure 3.Analysis Result of Seepage in Existing Condition

The amount of pore water pressure from the riser piezometer analysis and readings at each piezometer tip location is shown in Table 3. 
Table3. Pore water pressure from the riser piezometer analysis and readings

\begin{tabular}{ccccc}
\hline Piezometer & $\begin{array}{c}\text { Coordinate } \\
\mathrm{x} \\
(\mathrm{m})\end{array}$ & $\begin{array}{c}\text { Coordinate } \\
\mathrm{y} \\
(\mathrm{m})\end{array}$ & $\begin{array}{c}\text { Analysis } \\
\text { Result } \\
(\mathrm{kPa})\end{array}$ & $\begin{array}{c}\text { Reading } \\
\text { Result } \\
(\mathrm{kPa})\end{array}$ \\
\hline OP3.1 & 79.875 & 11.050 & 0.000 & 0.000 \\
OP3.2 & 79.875 & 6.516 & 42.063 & 46.482 \\
OP3.3 & 79.875 & 1.252 & 93.358 & 91.200 \\
OP4.1 & 93.375 & 6.993 & 30.105 & 21.672 \\
OP4.2 & 93.375 & 1.404 & 84.935 & 87.571 \\
\hline
\end{tabular}

The validation test of the piezometer data from the observations and analysis results yielded an RMSE value of 4.552, NSE of 0.984 with a "good" category and a correlation coefficient (R) of 0.992 indicating a " very strong" category. So, it can be concluded that the value of the pore pressure of the analysis results is close to the observed results. So that the calibration result data can be used for further seepage analysis. The data from the calibration results are used for further analysis, as shown in Table 4.

Table 4. Permeability Coefficient (K) Data Calibration Result

\begin{tabular}{ccc}
\hline Zone & Material & $\mathrm{K}(\mathrm{cm} / \mathrm{sec})$ \\
\hline Zone 1 & Soil & $1.04 \times 10^{-3}$ \\
Zone 2 & Filter & $1.00 \times 10^{-3}$ \\
Zone 3 & Toe drain & $1.00 \times 10^{-2}$ \\
Zone 4 & Riprap & $1.00 \times 10^{-1}$ \\
Zone 5 & Backfill materials & $1.00 \times 10^{-4}$ \\
Zone 6 & Foundation & $2.10 \times 10^{-3}$ \\
\hline
\end{tabular}

The damage in the geomembrane on the dam body can conclude that as the defect width increases and the defect location decreases, the seepage discharge will increase. If there is no damage to the geomembrane and the resulting seepage discharge is constant. The phreatic level is affected by the width of the defect. The wider the defect, the higher the phreatic level. However, the flow pattern at each defect width at the same location showed insignificant differences (Figure 4).

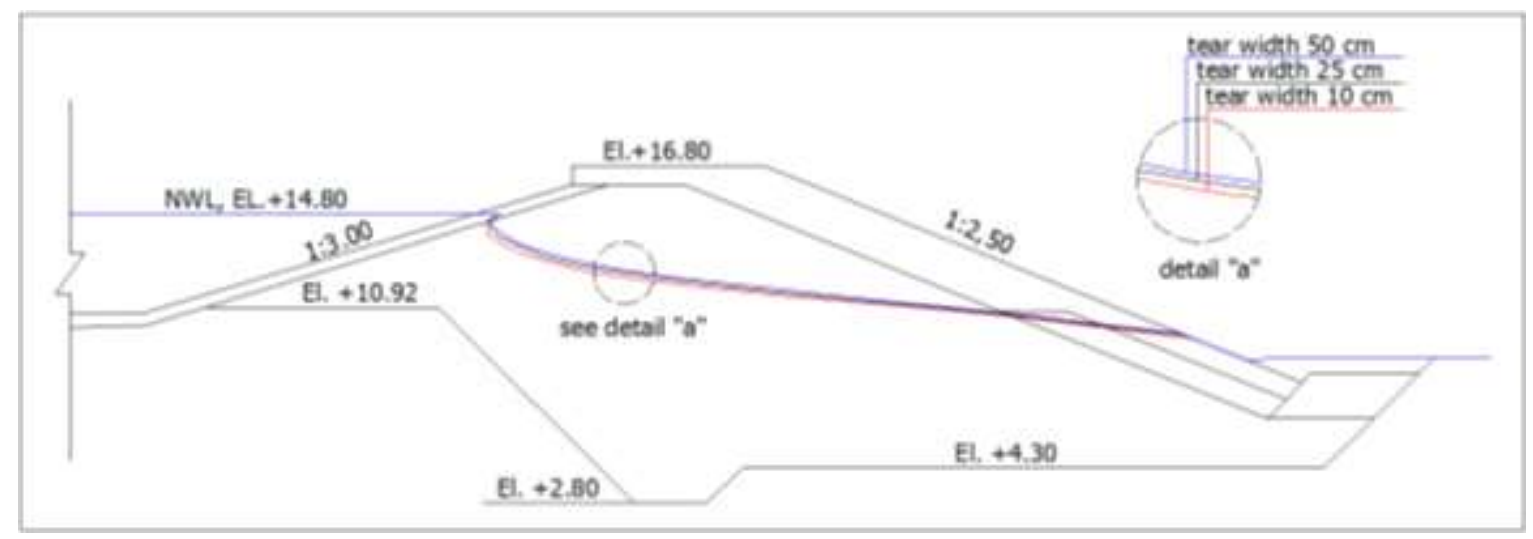

a) phreatic line on damage location on the upper part of geomembrane layer 


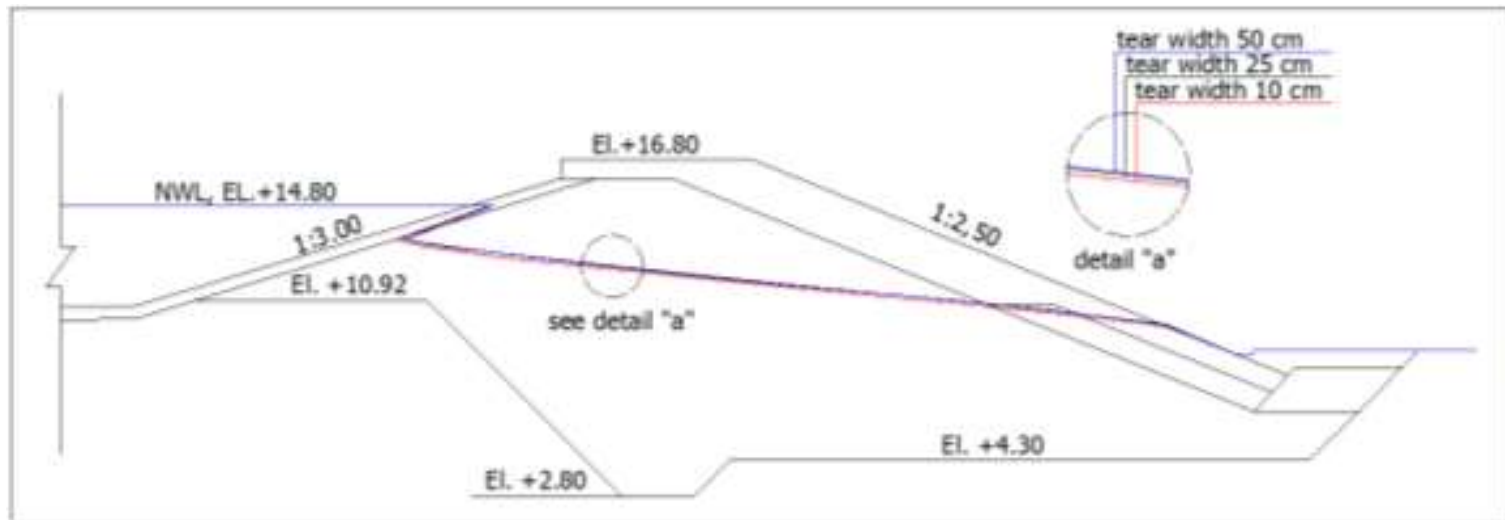

b) phreatic line on damage location on the middle part of geomembrane layer

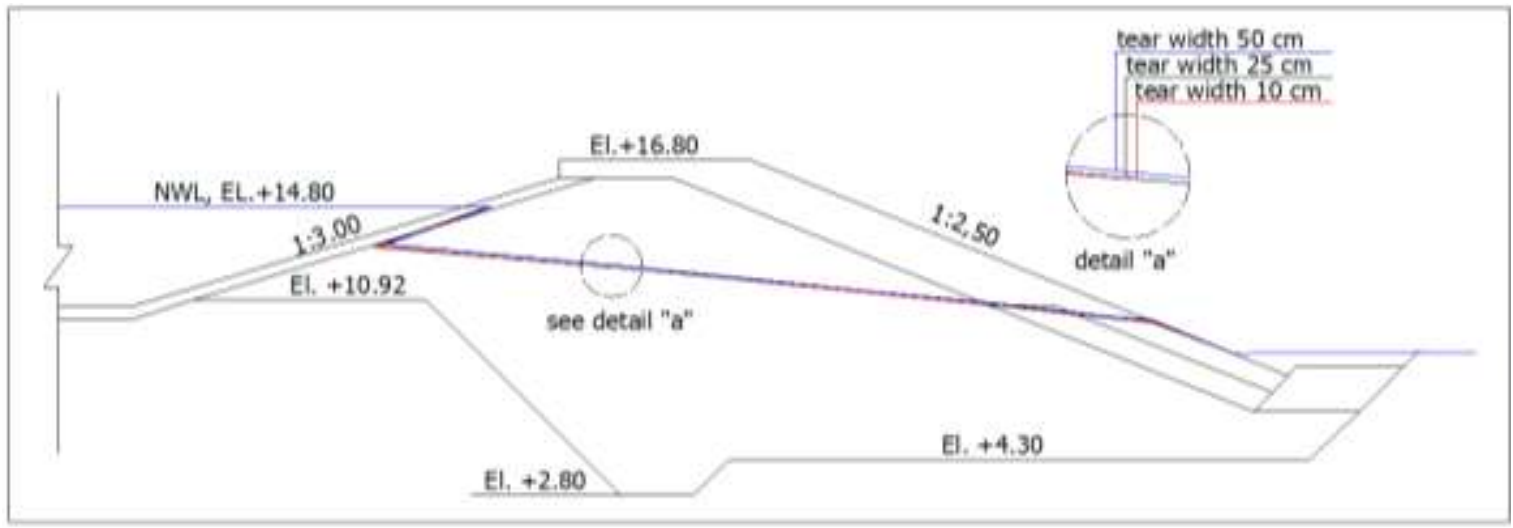

c) phreatic line on damage location on the lower part of geomembrane layer

Figure 4.Flow Pattern (phreatic lines) on the dam body with various damage locations and defect width in the geomembrane layer.

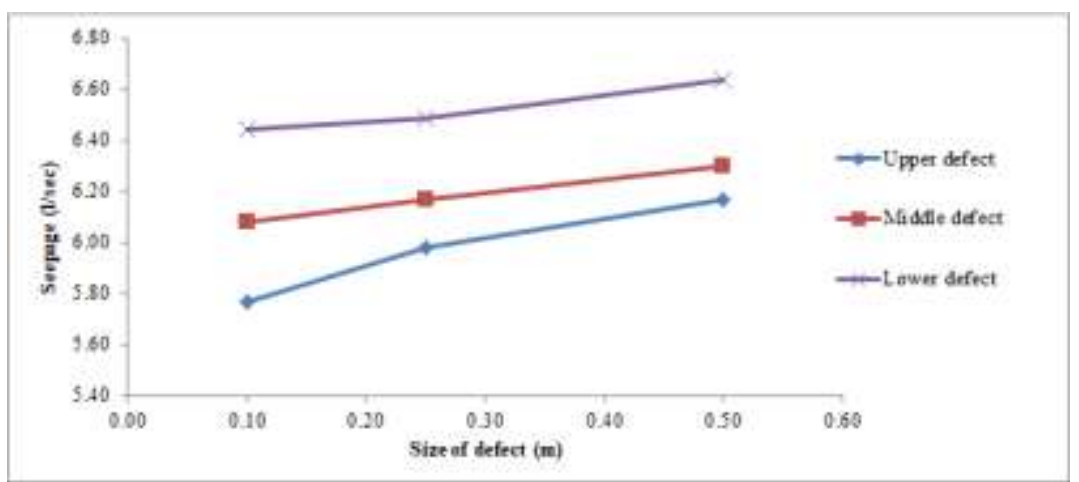

Figure 5. The influence of the size and location of the defect to the seepage discharge

The analysis results show that the amount of seepage discharge for defect widths of 10,25 and 50 $\mathrm{cm}$ is $2.71 \times 10^{-5}, 2.76 \times 10^{-5}$ and $2.79 \times 10^{-5} \mathrm{~m}^{3} / \mathrm{s} / \mathrm{m}$ respectively. The bigger the defect, the greater the seepage discharge through the dam's foundation and body. The amount of seepage discharge for a 10 $\mathrm{cm}$ defect width is $5.23 \mathrm{l} / \mathrm{s}$ or $1.94 \%$ of the mean annual inflow. The seepage discharge for the $25 \mathrm{~cm}$ defect width was $5.33 \mathrm{l} / \mathrm{s}$ or $1.98 \%$ of the mean annual inflow. Furthermore, the seepage discharge for a defect width of $50 \mathrm{~cm}$ is $5.38 \mathrm{1} / \mathrm{s}$ or $2.00 \%$ of the annual mean inflow. The amount of seepage discharge that occurs is less than the permit seepage discharge in terms of quantity. The allowable 
seepage discharge is $2.00 \%$ of the average annual inflow discharge (annual inflow $=0.27 \mathrm{~m}^{3} / \mathrm{s}$ ), or is $5.39 \mathrm{l} / \mathrm{s}$.

\section{Conclusions}

The seepage analysis results under existing conditions (without damage) show that the dam body's phreatic level tends to be lower. The low phreatic level is because there is an intact geomembrane layer in the dam's upper reaches. The seepage analysis in the supposedly damaged geomembrane layer shows that the greater the defect's width, the higher the phreatic line. However, the flow patterns that occur show an insignificant difference or nearly the same. During this time, the seepage discharge that occurs shows that with an increase in the defect's width and a decrease in the location of the defect, the seepage discharge will increase. The results show that damage to the geomembrane layer will result in leakage through the dam body. Therefore, a good design, construction and proper maintenance of the dam body's geomembrane layer is necessary so that leakage through the dam body can be avoided so that the dam body's safety can be awake.

\section{References}

[1] S. Sosrodarsono, K. Takeda, "Bendungan Type Urugan". Pradnya Paramita. Jakarta. 2002.

[2] Balai Bendungan. "Evaluasi Rembesan". Materi Bimbingan Teknis PemeriksaanBesar Bendungan. Balai Bendungan Direktorat Jenderal Sumber Daya Air. Jakarta. 2015

[3] Anonymous. "Laporan Akhir Evaluasi Penyempurnaan Konstruksi Waduk Sianjo Anjo".PT Wiratman \&Associates JO PT Citra Adiyasa Estima. Jakarta. 2017.

[4] Anonymous."Laporan Evaluasi Penanganan Bendungan Sianjo Anjo". PT Indra Karya (Persero) Divisi Engineering I JO PT Tuah Agung Anugerah \& PT Aztindo Rekaperdana. Banda Aceh. 2020.

[5] Anonymous. "Laporan Ringkas Persiapan Pengisian Pertama Pembangunan WadukSianjo Anjo". PT Wiratman \&Associates. Jakarta. 2007.

[6] W. Cen, H. Wang, D. Li, "Seepage Properties of Geomembrane Faced Sandy-Gravel Dams With Different Dam Heights Due to Defect-Induced Leakage". Advances in Engineering Research (AER), volume 143, $6^{\text {th }}$ International Conference on Energy and Environmental Protection (ICEEP), pp. 1361-1365, 2017

[7] Anonymous. "Final Laporan Akhir Pekerjaan SID Embung Sianjo Anjo dan EmbungRimo di Kabupaten Aceh Singkil". PT Resco Nusantara Consultan. Jakarta.2001.

[8] Anonymous. "Laporan Geologi dan Mekanika Tanah Embung Sianjo Anjo dan EmbungRimo di Kabupaten Aceh Singkil". PT Resco Nusantara Consultan. Jakarta. 2001.

[9] S. Demirdogen, "Numerical Analysis of Leakage through Defective Geomembrane Liners in Embankment Dams". Thesis, Scholar Commons University of South Florida, 2018.

[10] Motovilov, Y.G., Gottschalk, L., Engeland, K. \& Rodhe, A. "Validation of a Distributed Hydrological Modelling Against Spatial Observations". Elseiver Agricultural and Forest Meteorology. $98: 257-277.1999$.

[11] Sugiyono. "Statistika Untuk Penelitian". Bandung: CV. ALFABETA. 2007

[12] R.H. Ardiansyah, Sobriyah, A.H. Wahyudi, "Pengaruh Fluktuasi Muka Air Waduk Terhadap Debit Rembesan Menggunakan Model Seep/W (Studi Kasus di Bendungan Benel, Kabupaten Jembrana, Bali)”, e-Jurnal Mariks Teknik Sipil, pp. 471-476, 2014.

[13] A.L. Huda, S. Prabandiyani R.W., Suharyanto, "Evaluasi Tekanan Air Pori dan Rembesan Pada Bendungan Panohan”, Reka Buana : Jurnal Ilmiah Teknik Sipil dan Teknik Kimia, 4 (2), pp 102-111, 2019.

[14] H.K. Shayan, E. A. Tokaldany, "Effects of Blanket, Drains, and Cutoff Wall on Reducing Uplift Pressure, Seepage, and Exit Gradient Under Hydraulic Structures", International Journal of Civil Engineering, Vol. 13, No. 4A, Transaction A: Civil Engineering, pp. 486-500, 2015.

[15] Juwono, P., Asmaranto, R., \& Murdhianti, A. (2020). Stability of Existing Banyukuwung DAM in Recent Hydrology and Geotechnical Conditions. Civil and Environmental Science Journal 
(Civense), 3(2), 60-71. doi: https://doi.org/10.21776/ub.civense.2020.00302.1.

[16] I.N. Aribudiman, M.D.W. Ardana, I G. N Oka Suputra, "Penggunaan Program Geo-Studio Seep/W Untuk Menentukan Rembesan Air Lindi Pada Tanah Lempung", Jurnal Ilmiah Teknik Sipil - A Scientific Journal Of Civil Engineering, Vol. 22, No.2, pp 108-113, 2018.

[17] Y. Astuti, A. Masrevaniah, S. Marsudi, "Analisa Rembesan Bendungan Bajulmati Terhadap Bahaya Piping Untuk Perencanaan Perbaikan Pondasi”, Jurnal Teknik Pengairan, Vol. 3, No. 1, pp. 51-60, 2012.

[18] I.G.N. Putu Dharmayasa, “ Analisis Rembesan Di Bawah Tubuh Bendungan Urugan”, Jurnal PADURAKSA, Vol.7, No. 1, pp.53-62, 2018.

[19] Sudirman," Eksperimental Pola Aliran dan Rembesan Di Bawah Pondasi Bendungan Urugan Tanah", Jurnal Ilmiah Techno Entrepreneur Acta, Vol. 5 No.1, pp. 67-75, 2020.

[20] A. Imron, D. Sarah, S. Hardiyati, K. W. Sadono, "Analisa Geoteknik Bendungan Gongseng Terhadap Keamanan Rembesan, Stabilitas Lereng Dan Beban Gempa", Jurnal Karya Teknik Sipil, Vol. 6, No.1, pp. 185 - 192, 2017.

[21] EN Cahya, E Arifi, R Haribowo. 2020. Recycled porous concrete effectiveness for filtration material on wastewater treatment. International Journal 18 (70), 209-214. DOI: https://doi.org/10.21660/2020.70.9266. 